\title{
醱酵, 食糧工業への殺菌剤の応用
}

一般に微生物を死隇せしめる方式は熱殺菌と冷殺菌と に大別できるが，これらはさらに次のようにわけること ができる。

熱殺菌……乾熱殺菌, 湿熱殺菌

冷殺菌……放射線殺菌（紫外線， $\beta$ 線， $\gamma$ 線なぞ）, 除菌 (濾過, 遠心分離), 薬剂殺菌

これらのうち醱酵, 食糧工業の分野に沶いては湿熱殺 菌が最もひろく用いられているが，その他の方式も特殊 な面に利用されている。微生物汶対し殺菌作用を有する 薬侴は古くより多数しられているが, 有効性, 毒性, 残 留性, 価格などの点より応用範囲には限度がある。本稿

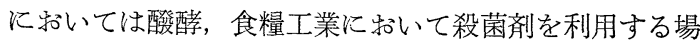
合の基礎的な諸問題と第 1 表に示した薬剤の応用につい て概説することにしたい。

\section{芝崎勲*}

\section{I. 薬剤殺菌の基礎的問題}

現在すべての要求を充たすような理想的な殺菌剤はみ あたらない。従って有効適切な利用のためには各薬剤の 殺菌作用特性はもらろん応用上の諸問題点をも充分把握: して㤸かねばならない。

\section{1）殺菌作用}

薬剂を殺菌の目的に利用するためには当然広範囲の微、 生物汇対し有効かつ作用が強力であるべきである。一般 にハロダン系殺菌剤（以下 Halogen と略称する）やガ ス殺菌剤は広範な微生物に対し殺菌性を示すが，作用力 の点では後者は通常の適用条件下では弱い。第 1 図には 種々の微生物に対するエチレンオキサイド (EO) の殺菌 力を示した1)。カチオン界面活性剤（逆性石鹼, 以下 Quat 々略称する）は病源菌などに対してはきわめて殺

第 1 表 a) 塩素系殺菌剂

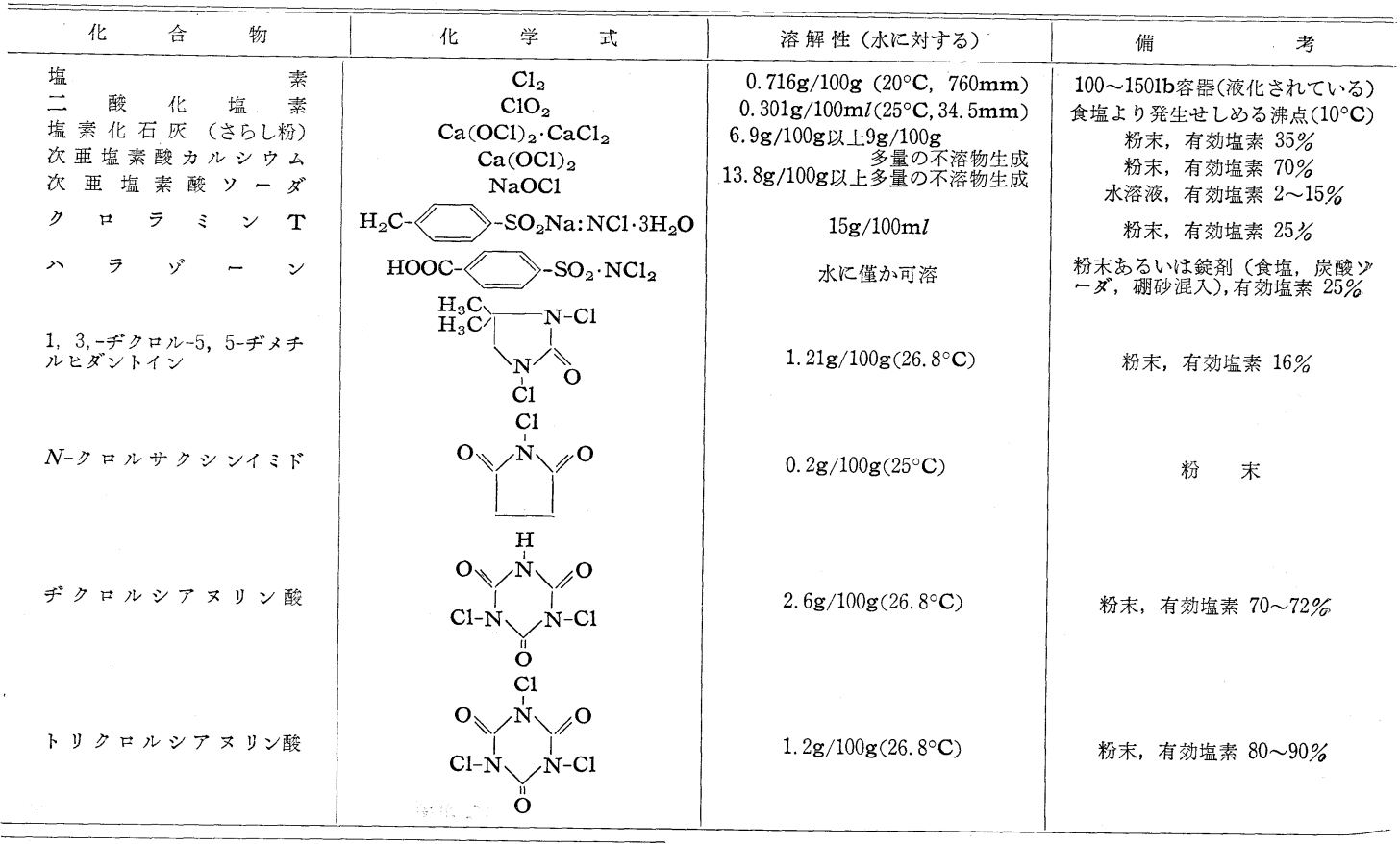

* 大阪大学工学部醴酵工学教室 
第1表 b) カチオン界面活性剤（逆性石䲓）

Alkyldimethylbenzyl ammonium chloride $\left[\begin{array}{c}\mathrm{CH}_{3} \\ \mathrm{R}-\mathrm{N}-\mathrm{CH}_{2}- \\ \mathrm{C} \mathrm{H}_{3}\end{array}\right]^{+} \mathrm{Cl}^{-} \quad \mathrm{R}=\mathrm{C}_{8} \sim \mathrm{C}_{18}$

Cetyltrimethyl ammonium bromide $\left[\mathrm{CH}_{3}\left(\mathrm{CH}_{2}\right)_{1-}{ }_{5}\left(\mathrm{CH}_{3}\right)_{3} \mathrm{~N}\right]^{+} \mathrm{Br}^{-}$

Cetylpyridinium chloride (bromide)

$$
\left[\mathrm{CH}_{3}\left(\mathrm{CH}_{2}\right)_{1-5} \mathrm{~N}-\longleftrightarrow\right]^{+} \mathrm{Ci}^{-}\left(\mathrm{Br}^{-}\right)
$$

Diisobutylphenoxyethoxyethyl dimethylbenzylammonium chloride

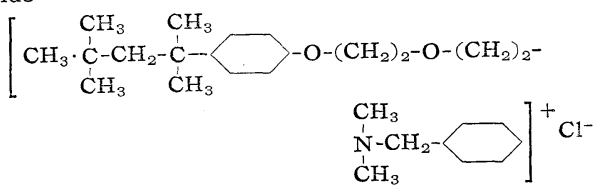

$N$-acylcolaminoformylmethyl pyridinium chloride $\left[\mathrm{CH}_{3}\left(\mathrm{CH}_{2}\right)_{n}-\stackrel{\mathrm{O}}{\mathrm{C}}-\mathrm{O}-\mathrm{CH}_{2} \mathrm{CH}_{2}-\stackrel{\mathrm{H}}{\mathrm{N}}-\stackrel{\mathrm{I}}{\mathrm{C}}-\mathrm{CH}_{2}-\mathrm{N}-\longrightarrow\right]^{+} \mathrm{Cl}^{-}$
菌力は強いが，ある種のもの（例えばPseudomonas）で は作用の弱いことが見出されている。細菌胞子は加熱, 放射線に対して抵抗性が大であるが，薬剤の場合にも同 様なことがいえる。Quat は常温では細菌胞子に対し殺 菌作用は彁い。

Halogen は胞子に対しても強力な作用力をもっている が, 菌種, 菌株により殺菌力は無胞子細胞の 1/10～1/1000 で女り, 中温細菌より高温細菌の胞子の方が抵抗性が大 きいことが認められている。ガス殺菌剤は Halogen そ の他の殺菌剤とことなり, 胞子に対しても比較的強く, 殺菌力の比率も1/5〜1/100 程度である。しかし溶液とし ての適用では第 2 図に示すようにホルムアルデヒドやエ ポオキサイドは微弱である2)。

フェノールやアルコールなどでは殺菌に対する薬剤濃 度効果は大きく濃度指数 $(n)$ が 4 11 であるが, Halogen やガス殺菌剤では $n=1 \sim 2$ の範囲にある ${ }^{2}(n=1$ の

第 1 表 c) ガス殺菌剤

\begin{tabular}{|c|c|c|c|c|c|c|c|c|}
\hline 楽 品 名 & 化学 式 & 燃 焼 性 & 透 過 性 & 性 & $\begin{array}{l}\text { 適用される } \\
\text { 殺菌濃度 }\end{array}$ & 殺 菌 力 & 適用湿度 & その 他 \\
\hline $\begin{array}{l}\text { エチレンオキサイ } \\
\text { ド }\end{array}$ & $\begin{array}{l}\mathrm{O}^{\mathrm{CH}}-\mathrm{CH}_{2} \\
\mathrm{bp} 10.4^{\circ} \mathrm{C}\end{array}$ & $\begin{array}{l}\text { 燃燒限界 } \\
3.6 \sim 100 \%\end{array}$ & 強 & W & $\begin{array}{r}400 \sim 1,000 \\
\mathrm{mg} / l\end{array}$ & $\begin{array}{l}\text { 中程度の殺 } \\
\text { 菌力 }\end{array}$ & $25 \sim 50 \%$ & $\begin{array}{l}\text { 安全のため不活性ガス例 } \\
\text { 亮ば宸酸ガス, ハロゲン } \\
\text { 化炭化水素にて稀釈 }\end{array}$ \\
\hline $\begin{array}{l}\text { プロピレンオキサ } \\
\text { イド }\end{array}$ & $\begin{array}{c}\mathrm{CH}_{3}-\mathrm{CH}-\mathrm{CH}_{2} \\
\mathrm{bp} 34.0^{\circ} \mathrm{C}\end{array}$ & $\begin{array}{l}\text { 燃燒 限界 } \\
2.1 \sim 21.5 \%\end{array}$ & 比較的強、 & & $\begin{array}{r}800 \sim 2,000 \\
\mathrm{mg} / l\end{array}$ & $\begin{array}{l}\text { エチレンオ } \\
\text { キサイドよ } \\
\text { り弱い }\end{array}$ & $25 \sim 50 \%$ & $\begin{array}{l}\text { 安全のため稀釈されるこ } \\
\text { とあある }\end{array}$ \\
\hline ホルムアルデヒド & $\mathrm{H} \cdot \mathrm{CHO}$ & $\begin{array}{l}7 \sim 73 \% \\
\text { が限界 }\end{array}$ & 弱 & w & $3 \sim 10 \mathrm{mg} / l$ & $w$ & $>75 \%$ & 表面殺菌剂として利用 \\
\hline メチルブロマイド & $\underset{\mathrm{bp} 4.6^{\circ} \mathrm{C}}{\mathrm{CH}_{3} \mathrm{Br}}$ & 不 燃 性 & 強 & w & $\begin{array}{l}3,500 \\
\mathrm{mg} / l\end{array}$ & 弱 & $40 \sim 70 \%$ & $\begin{array}{l}\text { かび, 細菌（無胞子）の } \\
\text { 殺菌用 }\end{array}$ \\
\hline $\begin{array}{l}\beta \text {-プロピオラク } \\
\text { トン }\end{array}$ & $\begin{array}{l}\mathrm{CH}_{2}-\mathrm{CH}_{2} \\
\stackrel{\mathrm{O}}{\mathrm{bp} 163^{\circ} \mathrm{C}}-\mathrm{CO}\end{array}$ & $\begin{array}{l}\text { 室温で不燃 } \\
\text { 性 }\end{array}$ & 弱 & W & $2 \sim 5 \mathrm{mg} / l$ & 極めて強い & $>75 \%$ & 表面殺菌剂 \\
\hline クロールピクリン & $\begin{array}{r}\mathrm{CCl}_{3} \mathrm{NO}_{2} \\
\text { bp } 112^{\circ} \mathrm{C}\end{array}$ & 燃焼性少い & 強 & w & $16 \mathrm{mg} / l$ & 比較的強い & & \\
\hline $\begin{array}{l}\text { エチンンヂブロマ } \\
\text { イド }\end{array}$ & $\begin{array}{l}\mathrm{CH}_{2} \mathrm{Br} \cdot \mathrm{CH}_{2} \mathrm{Br} \\
\mathrm{bp} 131.6^{\circ} \mathrm{C}\end{array}$ & 不 燃 性 & 比較的強 & & - & 弱 & & $\begin{array}{l}\text { 不反応稀僠剂で稀勫して } \\
\text { 用 } 5\end{array}$ \\
\hline
\end{tabular}

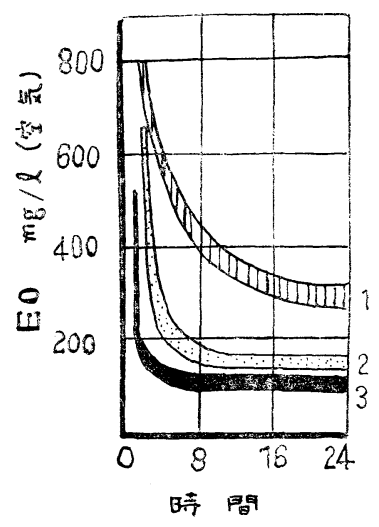

第 1 図 エチレンオキ サイドの殺菌力

第 58 巻 第 4 号 $22^{\circ} \mathrm{C}$, 関係湿度 30

$1 ：$ 芽胞細菌

B. subtilis, B.megaterium

$2 ：$ 無胞子細菌

Chromobacterium $s p$.

Pseudomonas aeruginosa

$3:$ が，酵母

Rhodotorula sp., Pullularia pullulans, Penicillium sp., Aspergillus sp.

場合濃度を 2 倍にすると殺菌速度は 2 倍となる)。

\section{2) 作用温度効果}

薬斉の殺菌作用は種々の条件注影響をうける。作 用温度は殺菌剤使用上に打いて重要な因子であって, 一 般に温度上昇と共に殺菌力は增大する。例えば次亜塩素 酸ソーダやエポオキサイドでは温度係数 $Q_{10}$ が大体 2 〜3の範囲にある $\left(-10^{\circ} \sim 50^{\circ} \mathrm{C}\right)^{2)}$ 。微生物は発育限界温 度を越えた環境では存在する物質の影響を受け易いが, 死隇を促進する物質に関しては多数の研究がある。第 2 表に示したのは Michener $5^{3)}$ が Clostridium sp. PA 3679 の胞子の熱抵抗性を低下せしめる物質を検索し（約 650)，とくに効果のあるものとして 26 物質をあげてい るが，ここにとの 1 部を示した。この例では薬剤共存下 

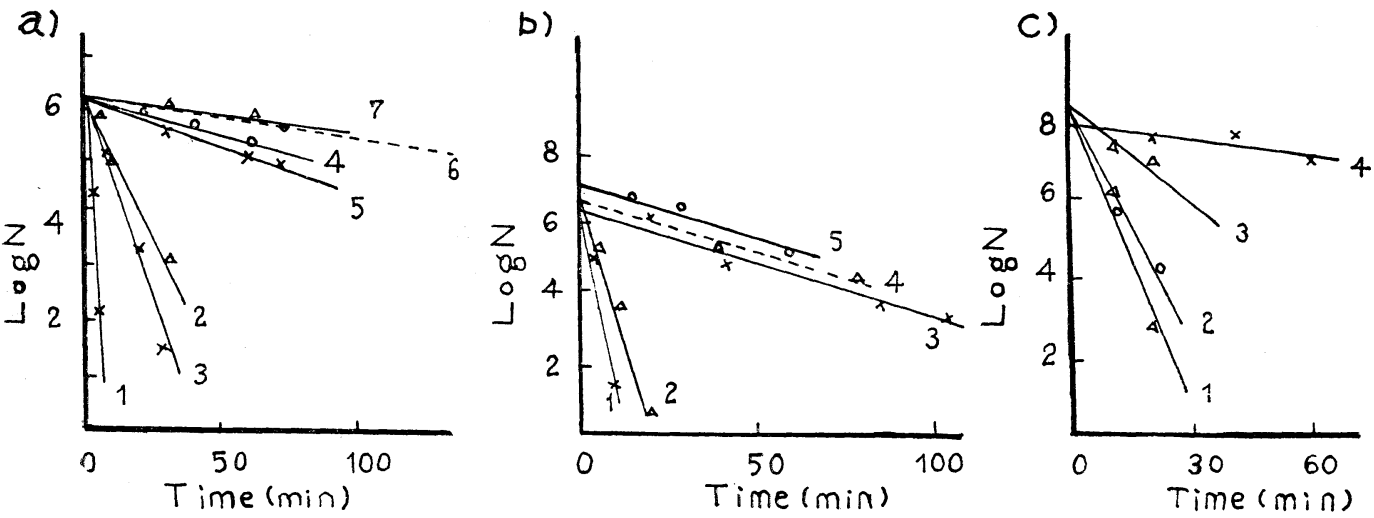

第 2 図水溶液中での殺菌作用

a) Phosphate buffer $(\mathrm{pH} 7.0) ; 30^{\circ} \mathrm{C}$.

Test organism : B. subtilis spores.

$1: \mathrm{NaClO}, 0.8 \mathrm{mM} / l$.

$2: \mathrm{NaClO}, 0.16 \mathrm{mM} / l$.

$3: \mathrm{PL}, 0.16 \mathrm{M} / l$.

$4: \mathrm{PL}, 0.016 \mathrm{M} / l$.

$5: \mathrm{F}, 0.33 \mathrm{M} / l$.

$6: \mathrm{EO}, 0.5 \mathrm{M} / l$.

$7: \mathrm{PO}, 1.43 \mathrm{M} / l$. b) Phosphate buffer $(\mathrm{pH} 7.0) ; 30^{\circ} \mathrm{C}$

$1: \mathrm{PL}, 0.16 \mathrm{M} / l$, Es. coli.

$2: \mathrm{F}, 0.16 \mathrm{M} / l$, Es. coli.

$3: \mathrm{F}, 0.0033 \mathrm{M} / l$, Ps. aeruginosa.

$4: \mathrm{F}, 0.033 \mathrm{M} / l$, Micro. flavus.

$5: \mathrm{F}, 0.033 \mathrm{M} / l$, Ser. marcescens.

c) $1: \mathrm{PO}, 1.43 \mathrm{M} / l$, Ps. aeruginosa.

$2: \mathrm{PO}, 1.43 \mathrm{M} / l$, Ser. marcescens.

3 : EO, $0.05 \mathrm{M} / l$, Ps. aeruginosa.

$4: \mathrm{PO}, 0.36 \mathrm{M} / l$, Es. coli.

$\mathrm{F}:$ ホルムアルデヒド, $\mathrm{EO}:$ エチレンオキサイド, PO：プロピレンオキサイド, PL : $\beta$-プロピオラクトン

第 2 表

Clostridium PA 3679 胞子数 $6 \times 10^{5}, 113^{\circ} \mathrm{C}, 14$ 分

\begin{tabular}{|c|c|c|}
\hline 薬 & $\begin{array}{c}\text { 濃 } \\
(\mathrm{ppm})\end{array}$ & $\begin{array}{l}D \text { 值 }(90 \% \text { 死隇に要す } \\
\text { る時間) の低率 }(\%) \\
\end{array}$ \\
\hline ホルムアルデヒド & 100 & 70 \\
\hline 過 酸 化 水 素 & 700 & 70 \\
\hline СТАB* & 600 & 70 \\
\hline エチレンオキサイド & 300 & 65 \\
\hline プロピレンオキサイド & 2,000 & 70 \\
\hline 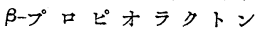 & 3,000 & 65 \\
\hline ナ & 40 & 65 \\
\hline サ ブ チ リ & 7 & 65 \\
\hline
\end{tabular}

* Cetyl trimethylammonium bromide

での効果をみているが，別々に処理する場合にも加成的 ないしは相乗的な効果の期待される場合が多い。Rodeら は Quat の存在により細菌胞子の熱抵抗が著しく低下す ることを認めている゙)。エポオキサイドは低温では殺菌 作用は緩慢であるが第 3 表に示したように高濃度を用い $55^{\circ} \mathrm{C}$ 以上で作用せしめる場合，熱抵抗性の極めて強い B. stearothermophilus, Clostridium PA 3679 などの胞 子に対して短時間体菌できることが示されている5)。 これらの研究結果より可及的高温で作用さす方が有利で あることが明らかである。

\section{3）作用 $\mathrm{pH}$ 効果}

殺菌剤の化学的性質より作用時の $\mathrm{pH}$ は殺菌力に著し い影響を与兄る。Halogen と Quat では有効 $\mathrm{pH}$ 範囲 は逆の傾向沉り前者は酸性側傜, 後者はアルカリ側で
第3表 エポオキサイドによる細菌胞子の殺菌 B. stearothermophilus (NCA FS 1518), Clostridium PA 3679 の胞子を金属製血で乾燥したものを使用する

\begin{tabular}{|c|c|c|c|c|c|}
\hline & \multicolumn{5}{|c|}{ 殺菌に要する時間（分） } \\
\hline 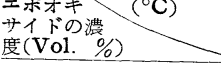 & $54.5^{\circ}$ & $66^{\circ}$ & $77^{\circ}$ & $88^{\circ}$ & $98^{\circ}$ \\
\hline $\begin{array}{c}\text { エチレンオキサイト } \\
0 \text { (湿熱) } \\
10 \\
20 \\
40 \\
60 \\
80 \\
90 \\
95 \\
100 \\
\end{array}$ & \begin{tabular}{c|}
125 \\
90 \\
62 \\
28 \\
14 \\
8.7 \\
7.5
\end{tabular} & $\begin{array}{c}47 \\
33 \\
21 \\
10 \\
4.8 \\
3 \\
2.6 \\
150+ \\
\end{array}$ & $\begin{array}{c}60,000+ \\
17.5 \\
12.5 \\
7 \\
3.4 \\
1.8 \\
1.1 \\
0.9 \\
8.0+\end{array}$ & $\mid \begin{array}{l}6.000+ \\
6.5 \\
4.7 \\
2.4 \\
1.2 \\
0.6 \\
0.4 \\
0.3 \\
5.0+ \\
\end{array}$ & $\begin{array}{r}600+ \\
2.6 \\
1.7 \\
0.8 \\
0.4 \\
0.2 \\
0.1 \\
0.1\end{array}$ \\
\hline $\begin{array}{c}\text { プロピレンオキサ1 } \\
\text { ケ濃度 } \\
\text { (\%. Vol) } \\
0 \text { (湿熱) } \\
10 \\
20 \\
40 \\
60 \\
80 \\
90 \\
98 \\
100\end{array}$ & $\begin{array}{r}1,250 \\
810 \\
375 \\
185 \\
90 \\
63 \\
47 \\
25,000 \\
+\end{array}$ & $\begin{array}{c}540 \\
360 \\
160 \\
74 \\
36 \\
23.5 \\
17.0 \\
5,000+\end{array}$ & $\begin{array}{c}60,000+ \\
240 \\
160 \\
70 \\
31 \\
14.4 \\
8.8 \\
6.1 \\
1.000+\end{array}$ & $\begin{array}{c}6,000+ \\
105 \\
70 \\
30 \\
13.1 \\
5.8 \\
3.3 \\
2.2 \\
300+\end{array}$ & $\begin{array}{c}600+ \\
46 \\
31 \\
13 \\
5.6 \\
2.3 \\
1.2 \\
1.0 \\
200+\end{array}$ \\
\hline
\end{tabular}

強力に㗢く。しかし halazone, dichloramine-T, cetylpyridinium chlorideなどのよう沈あり $\mathrm{pH}$ に影響さ れないすのもある。

\section{4）環境物質の影響}


Halogen 法反応性に富むので存在する有機物乞の他還 元性物質により殺菌力が著しく低下する。るちろんこの 中でも $\mathrm{ClO}_{2}$ とか後述する iodophor のように影響され 難いものも岕るしかし界面活性剤々の他洗剂炕よる影 響は少なく，ときに作用効果の増強されることもある。 Quat は Halogen 程有機物に依る低下はないが, 蛋白質 などによる低下は著しい。さらに非イオン性活性剤や石 鹼などのアニオン性界面活性剂, ポり燐酸塩, 燐脂質な ぞにより殺菌力の低下がある。以上二者に比しガス殺菌 剂は環境物質の影響は少なく, 多量の有機物の存在下で る殺菌可能である。しかしガス状で作用さす場合共存す る水蒸気の影響は著しく, 従来はホルムアルデヒドや $\beta-$ プロピオラクトンは高湿度側に，エポオキサイドは低湿 側传菌作用の最適があるといわれている。乙かし最近 エポオキサイドの場合第 3 表の結果でも明らかなように 強力な作用を示すためには少量の水分が必要であり ${ }^{5)}$, またHimmelfarb ら゙は菌種により若干の変動はある が，何れも高湿度になる程殺菌時間が短縮されることを 示している。著者らは外界の湿度はもらろん対象とする 材料, さらに溦生物自体の平衡水蒸気圧をも問題にす べきであると考穴詳細な検討を行なっている7。

\section{5）その他}

他の殺菌方式でる同様であるが, 適用する対象物に与 える影響を十分考慮する必要がある。ことに薬剤殺菌に 扣いては人体注対する毒性, 残留性, 材質, 品質などに 対する影響は重要である。Halogenの内塩素, 次互塩素 酸塩, クロラミンTなどは食品衛生法で合成殺菌料とし て便用が許可されているが，これは無制限に用いてよい ものでなく, 残留しても微量で毒性少なく, 反応生成物 も悪影響が潘とんでないという前提条件が含まれる筈で ある。

Quat やガス殺菌剤は食品添加物に入っていないが， 適用に当っては Halogen 以上の注意が肝要である。反 応性は Halogen より遙が弱いが，Quat は吸着性が つよく, 容器などの表面殺菌後に捯いても存在しこれが 静菌的に働く面はよいが，これと接触した食品などに移

第 4 表 殺菌剂の特性

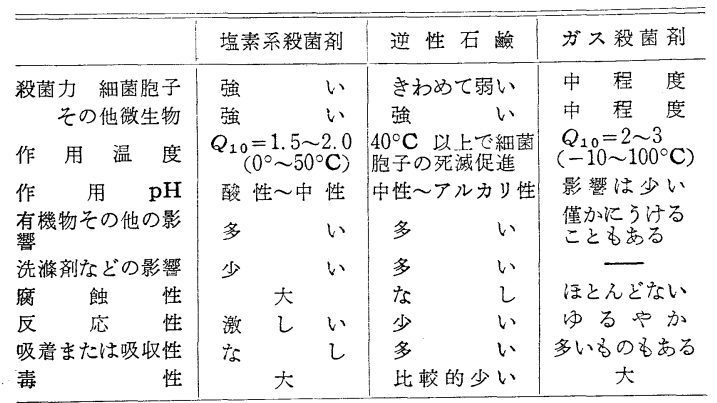

行する可能性もある。従って容器などは殺菌後は十分洗 滌する必要がある。エポオキサイドなどのガス殺菌剤は そのものの残留性の外浽応生成物あるいは分解物も問 題視される。米国などではエポオキサイドの処理食品中 の残存量の規定はしているが, 近年以上の点について再 検討されつつある。

以上殺菌剤の基礎的問題点をのべたが殺菌剤の特質を まとめて比較したものが第 4 表である。

\section{II. 各殺菌剤の応用}

\section{1）八ロゲン系殺菌荗}

Plant sanitation の分野では無機の塩素系殺菌剤が古 くょり最もひろく利用されており，今更ここでとり岕げ る必要はないと思われるが 2,3 の使用基準を示してお

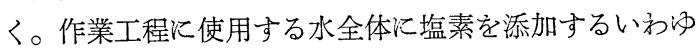
る “In-plant chlorination” では色々の型式の Chlorinator を用いて, 遊離有効塩素量を $5 \sim 7 \mathrm{ppm}$ に保持し, 掃除の際 15〜20 ppm まで増加せしめる（冷凍食品, 缶 詰などの工場で利用)。乳製品などのプラントで機械類や パイプラインなどの殺菌には有機物をよく洗滌してから 有効塩素量 $100 \mathrm{ppm} て ゙ 25^{\circ} \mathrm{C}, 2$ 分間処理するのが推奖 されている。この場合界面活性剂, 例えば $0.1 \%$ 程度の sodium lauryl sulfate を添加するときは殺菌力の增強 々共に処理表面の湿潤化にも役立つ。牛乳瓶などは洗涤 後, $100 \mathrm{ppm}$ 有効塩素量汇て殺菌し, 処理後充䍌器まで の $2 \sim 3$ 分コンベアー上を移動する間に完全に塩素臭は 消失するといわれている。これらの目的に利用される塩 素殺菌版は液化塩素が最も安価で多用されているが，こ の外次亜塩素酸ソーダ溶液も使用に便なるため多量消費 されている。沃素の殺菌作用汇ついても古くょり知られ ているが，最近種々の点より Plant sanitation への利 用が注目されている。その 1 つは非イオン界面活性剂と 沃素とを結合せしめ可溶性複合体としたものが市販され ている (Iodophors) ${ }^{8)}$ 。この特徵をあげると(1)酸性側で 冷水あるいは硬水中でも殺菌力が強い(2)水に易溶(3)普通 の濃度で人体浮無毒(4)皮膚に対しても害作用はない(5)腐 蝕性がない(6)着色性, 臭気がない(7)有機物の存在で有効 (8)渗透, 湿潤, 洗涤性がある(9溶液の着色度より存在す る沃素濃度が予想できる。

\section{2）カチオン界面活性凰}

医療, 公衆衛生などの分野での殺菌剤としてとくにす ぐれ広く利用さているが, 酸酸, 食糧の分野でもとの特 質をいかした応用面も多い。酪農, 缶詰, 製菓, 醸造な ぞの関係に扔いて, 材質や装置の性質上蒸気や塩素剤の 適用できないところに利用価值がある（諸設備, 器具, タンク，パイプナ:ぞ）。標準の使用濃度は 1/2000～1/5000 
第 5 表

\begin{tabular}{|c|c|c|c|c|c|c|c|c|c|c|}
\hline & & & & & \multicolumn{3}{|c|}{ 生 } & \multicolumn{2}{|c|}{ 数 } & \multirow[b]{2}{*}{ 後 } \\
\hline & & & & & 処 & 理 & 前 & 処 & 理 & \\
\hline 輸 & & 送 & & 罐 & \multicolumn{3}{|c|}{$14,000 \sim 1,100,000$} & \multicolumn{3}{|c|}{$40 \sim 800$} \\
\hline 重 & 量 & 計 & 出 & ㅁ & \multicolumn{3}{|c|}{970,000} & \multirow{2}{*}{\multicolumn{3}{|c|}{$\begin{array}{l}3,200 \\
2300\end{array}$}} \\
\hline 予 & 備 & タ & ン & $\eta$ & \multicolumn{3}{|c|}{$1,400,000$} & \multirow{2}{*}{\multicolumn{3}{|c|}{$\begin{array}{r}2,500 \\
800\end{array}$}} \\
\hline 洆 & 過 & ポ & ン & $フ^{\circ}$ & \multirow{2}{*}{\multicolumn{3}{|c|}{$\begin{array}{l}500,000 \\
980 ; 000\end{array}$}} & & & \\
\hline 眝 & 乳 & タ3 & ン & $\eta$ & & & & \multicolumn{3}{|c|}{920} \\
\hline パ & & イ & & $フ^{\circ}$ & \multicolumn{3}{|c|}{$3,400,000$} & \multicolumn{3}{|c|}{630} \\
\hline 殺 & 菌 & \$3 & v & $\eta$ & \multicolumn{3}{|c|}{460,000} & \multicolumn{3}{|c|}{740} \\
\hline
\end{tabular}

程度である。第 5 表に牛乳加工々程への適用効果例を示 g。

\section{3） ガス殺菌剤}

ガス殺菌剤については既に綜説》があるので最近の文 献よりひろった応用例を述べることにする。第 1 表 c) に代表的なものの特性をめげたが，第 6 表のごとき利用 分野がある。これらの特質は第 4 表よりも明らかである が，熱，水分に鋭敏な材料を殺菌でき，多量の材料でも

\begin{tabular}{|c|c|}
\hline ホルムアルデヒド & 病室などの空間, 医療器具, 薬品 \\
\hline エチレンオキサイド & 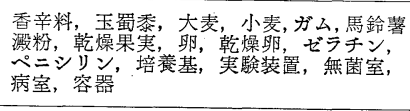 \\
\hline プロピレンオキサイド & 乾燥果実, 粉末食品, 容器 \\
\hline メチルブロマイド & 款 類 \\
\hline$\beta$-プロピオラクトン & 室内, 培養基, 卵 \\
\hline
\end{tabular}

滲透性がよいので簡単に容器あるいは包装中で多量の有 機物の存在下で殺菌できることである。ただ欠点として あげられるのは, 殺菌に比較的長時間を要すること, 薬 剤の取扱いが面倒なことである。

a) 装置類の殺菌 ${ }^{10)}$

装置飞 B. subtilis の胞子を附着せしめ, 殺菌容器と してオートクレーブ，ドラム缶，ポリエチレン袋を用い た場合の有効性を第 7 表に示した。この場合混合殺菌剤 (EO 11\%，ヂクロールヂフロールメタン $44.5 \%$,トリク ロールモノフロールメタン $44.5 \%$ ）の入った 16 オンス

第 7 表

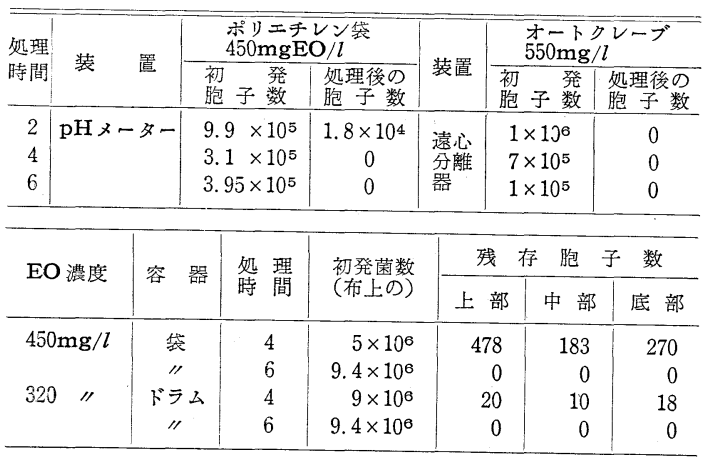

低圧エアロゾル缶を用い，簡単な操作でそれぞれの容器 に殺菌片を導入している。

b）乾燥食品の殺菌装置ならびに操作例 ${ }^{11}$

殺菌装置: 真空用殺菌容器 $\left(2 \mathrm{~m}^{3}\right.$ 容), 空気ポンプ, 加熱装置, 蒸発器, 空気濾過器

殺菌操作：材料をそのままあるいは包装したまま殺菌 容器に入れ, 真空にした後必要量のエチレンオキサイド を蒸発器にて蒸発せしめポンプで容器内に導入せしめ る。薬剂の蒸発には 30 秒位かかるが循環によって容器 全体に簡単に分布せしめることができる。ガスの導入に より真空度は低下するが約 $20 \%$ 位で殺菌する。一定時 間後排気を $2 \sim 3$ 回行ない次いで空気濾過器をと特した 空気により常圧にもどし, 殺菌された材料を取り出す。こ のような真空下での操作によりボール箱や合板でつくっ た容器につめた小麦, 澱粉, 香辛料などでも十分殺菌でき る。殺菌温度は $25 \sim 35^{\circ} \mathrm{C}$ 程度が最もよい。大抵の場合 エチレンオキサイド $500 \sim 700 \mathrm{mg} / l, 6$ 時間処理で殺菌 ができる。しかし食品中の菌数なぞにより 1000〜1250 $\mathrm{mg} / l$ 位必要な場合もある。殺菌剤としてはエチレンオ キサイドを単用する外，メチルブロマイド，プロピレン オキサイド，エステル類を混用した方が有利な場合も見 出されている。

c） $\beta$-プロピオラクトンによる密閉空間の殺菌 ${ }^{2)}$

倉庫, 病室, 無菌室など大きな密閉空間の殺菌にはガ ス殺菌剤が最も適当している。腐蝕性の点で塩素ガスや 亜硫酸ガスは利用できない。古くよりホルマリンはこの 目的に利用されているが，重合し易く対象物表面に附着 し殺菌濃度が急速に低下することが認められている。エ チレンオキサイドはこれらになさる点が多いが, 渗透性 が大で完全密閉容器以外では飛散し易く, また可然性の 点も問題となる。 $\beta$-プロピオラクトンは以上の諸点は問 題とならないし, 比較的安価 (\$0.50/1b) で, 細菌胞子 はもちろん Rickettsia，virusに対しても有効である （すでに血液，ワクチンなどの殺菌剤として注目されて (いる）。また水などの存在で速やかに加水分解されて $\beta$ オキシプロピオン酸（または塩）を生成して無毒化され る。推賞されている殺菌条件としては

温度 $\cdots 24^{\circ} \mathrm{C}$ 以上 湿度 $\cdots 70 \%$ 以上 薬剂濃度..

$$
2 \sim 4 \mathrm{mg} / l \text { (空気) 作用時間 } \cdots 2 \text { 時間 }
$$

薬剤の導入には普通の噴霧器や発生器(加熱による)が 用いられるが上述の濃度をらるためには普通 $9 \sim 12 \mathrm{mg} / \mathrm{l}$ (空気)を必要とする。殺菌が終れば少なくも1日は換気 ないしは通風するができるだけフアンを設備すべきであ る。

ここで注意を要するのは薬剤つ毒性であって, rat の 実験では 2 時間で $50 \%$ 致死量が約 $0.5 \mathrm{mg} / l$ (空気) で 
めり, 人間の感知できる最低濃度は $0.05 \mathrm{mg} / l$ (空気) で $0.1 \mathrm{mg} / l$ (空気) 以下でも 5 分間以上耐兄られないと いわれている。また皮膚に対しては紅疹や発泡を生ず る。 mouse での実験であるが皮膚に腫瘍つ発生するこ とも示されている。従ってガス吸入に対してはもらろ ん, 薬版刀取扱いにも特別つ注意が払われねばならな い。

\section{d）容器つ連続ガス殺菌法5)}

これは金属またはガラス容器表面を連続的にエポオキ サイドに接蝕せしめ短時間に殺菌する方法である。第 4 表に示すように高温で作用さすと耐熱性細菌胞子を6〜 60 秒程度で殺菌が可能でめる。殺菌後は蒸気流, 殺 菌 したガス岕るいは真空にすることにより除くことができ る。この方法は短時間比較的低温でしかも常圧下で殺菌 ができ腐蝕性なく安価な利点がある。本法の応用分野と しては種々の材質の容器類または材料の連続殺菌, その 他装置, 貯蔵タンクなどの迅速殺菌があげられる。しか 乙高濃度のエポオキサイドを高温 $\left(55^{\circ} \mathrm{C}\right.$ 以上) で作用さ すので食糧原料や乾燥食品ではとの品質に及棌す影響を 吟味して扮く必要がめる。第 3 図は容器の連続殺菌法の 系統図で女る。

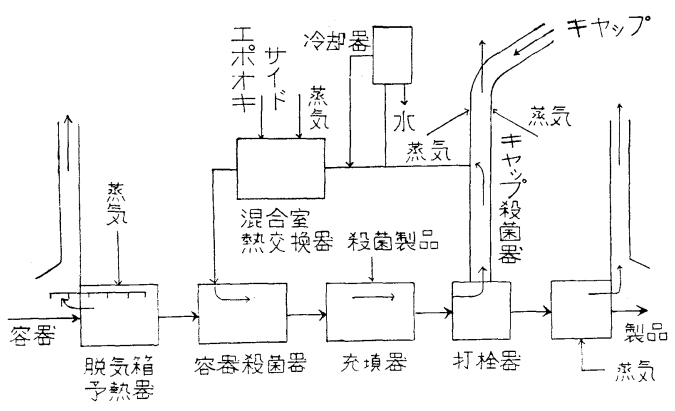

第3図エポオキサイドによる連続的容器殺菌

e）液状での応用例

最近の研究では培峑基の殺菌と卵拉よび卵製品の殺菌 があげられる。前者ではニチレンオキサイド, $\beta$-プロピ オラクトンが供試されて和り, 適当な濃度 $(0.5 \%$ 程度) を用うれば常温で数時間以内に殺菌ができ，一応色々の 微生物を培養しても従来法と大差ないことがみとめられ ている13)。後者では $\beta$ プロピオラクトンを食品（卵）に 添加して有害菌を死滅せしめょうとするもので, 毒性の 問題は今後の検討を要するが, 十分殺菌の可能なことが
認められている ${ }^{14)}$

以上著者は代表的な殺菌剂について, 醱酵, 食糧工業 の分野への応用についてのべたが，殺菌の目的に直接材 料中に混入することは過酸化水素（原料牛乳の殺菌にカ タラーゼと組合せて利用されている）のような特殊なも のは別として現在毒性の点で利用することはでさない。

従って応用はい放らるPlant sanitation の分野に限ら れてくる。しかし使用法つ簡単なるになかせて殺菌剤の みにたよるのは早計であって, 他の殺菌手段との関連に 和いて十分対象物の性質を考学て方法や薬剤を選択すべ きである。醉造関係に沶いても水分や加熱をさけるべき 対象虫殺菌剤にたよらざるを党ないが，通常の場合現段 階ではまず加熱殺菌を考光るべきであり, また一方殺菌 剂化加熱手段を組合せてより殺菌効果を大ならしめるよ らに心掛けるべきであろう。さらにガス殺菌剤を利用す る際通常の場合以上飞取扱い注意を払う必要がある。

\section{文献}

1) I. Z. J. Toth: Archiv. Mikrobiologie, 32, 409 (1959)

2) 芝崎, 照井: 酸酻工学, 40,125 (1962)

3) H.D.Michener, P.A. Thompson, J. C. Lewis: Applied Microbiology, 7, 166 (1959)

4) L. J. Rode, J.W. Foster : Archiv. Mikrobiologie, 36, 67, (1960)

5) J.E.W.McConnell, C.P.Collier : Food Eng., 34 (12) 96 (1962)

6) P.Himmelfarb, H. M. E1-Bisi, R.B. Read, W. Litsky : Applied Microbiology, 10, 431 (1962)

7) 芝崎，関，照井：日農化大会 (1963，4 月 2 日）発表予定

8) M.E.Parker, J.H. Litchfield : "Food plant sanitation", Reinhold Pub. Corp., New York (1962)

9) C.W.Brush : Ann. Rev. Micro., 15, 245 (1961) 芝崎; 食品之科学, 4 (8) 30 (1962)

10) D. G. Schley, R. K. Hoffman, C. R. Phillips : Applied Microbiology, 8, 15 (1960)

11) H. Rauscher, G. Mayr, H. Kaemmerer : Food Manufacture, 32, 169 (1957)

12) D. R. Spiner, R. K. Hoffman : Applied Microbiology, 8, 152 (1960)

13) I. Toplin, E. L. Gaden : J. Biochem. Micro. Tech. Eng., 3. 311 (1961) ; P. Himmelfarb, R. B. Read, W. Litsky: Applied Microbiology, 9, 534 (1961)

14) C.W. Brush, M. G. Koesterer : Applied Microbiology, 10, 123 (1962)

一般的な成畫及び綜説

M.E. Parker, J. H. Litchfield : "Food plant sanitation", Reinhold Pub. Corp., New York (1962)

W. A. Mercer, I. I. Somers : Adv. Food Res., VII, 130 (1957)

J. C. L. Resugan:"Quaternary ammonium Compounds in Chemical Sterilization", United Trade Press LTD., Lond. (1951)

C. G. Dunn: Adv. Food Res., II, 118 (1949)

G. Sykes: "Disinfection and Sterilization", D. Van Nostrand Co. Inc. (1958) 